\title{
Legal Relations and Responsibilities between Grantor and Grantee of Director's Attorney in the Implementation of Procurement of Government Goods and/ or Services (Study of the Decision of the Mataram District Court Number: 33/PID.SUS.TPK/2015/PN.MTR)
}

\author{
Dewi Agustina ${ }^{1}$; Zainal Asikin; Kurniawan ${ }^{2}$ \\ ${ }^{1}$ Graduate Program Student in Notary, Faculty of Law, Mataram University, Indonesia \\ ${ }^{2}$ Faculty of Law, Mataram University, Indonesia \\ http://dx.doi.org/10.18415/ijmmu.v6i3.746
}

\begin{abstract}
This study aims to determine the legal relations between grantor and grantees of director's attorney in the procurement of goods/ services based on the decision of the Mataram District Court Number: 33/PID.SUS.TPK/2015/PN.MTR. This study is a normative study that uses legislative, case, and conceptual approaches and uses primary and secondary legal materials. The research results lead to one conclusion. If it is associated with Article 1338 and 1320 of the Civil Code, legal relations between grantor and grantee of director's attorney are created when they have agreed to enter into an agreement. However, the agreement they made is not necessarily considered valid because the agreement of the director's attorney made by the two defendants including the nominee agreement in the procurement of government goods/ services is a matter which is not allowed to be carried out by business actors as the provider; moreover, it can be considered as an attempt to smuggle the law because it is considered not to fulfill one of the legal requirements of the agreement namely the existence of a cause or causal that is lawful and considered to be contrary to the principle of good faith in the agreement. Thus, the agreement of the director's attorney made by the two defendants is null and void.
\end{abstract}

Keywords: Legal Relations; Procurement of Goods and Services

\section{Introduction}

The development program in an area needs to be supported by the availability of an adequate regional infrastructure system. The government, in the construction of facilities and infrastructure to support the economy and service of the Indonesian people, is expected to truly carry out its role well; among them is improving public services, developing regional and national economies to realize the value of benefits as much as possible, and contributing to increasing use of sustainable development (Huraerah, 2008). 
Following up on the above matters, the government formulated a new regulation regarding procurement of government goods/ services through Presidential Regulation No. 16 of 2018 concerning Procurement of Government Goods/ Services in lieu of Presidential Regulation No. 54 of 2010 along with Amendments (finally by Presidential Regulation No. 4 of 2015 ) which are considered to still have shortcomings and have not accommodated the development of government needs regarding the appropriate regulation for the procurement of government goods/ services. ${ }^{1}$

Presidential Regulation No. 16 of 2018 concerning the Procurement of Government Goods/ Services, hereinafter referred to as Presidential Regulation No. 16 of 2018, is expected to accelerate and facilitate the implementation of Procurement of Government Goods/ Services into a convoluted and simple matter that provides value for money and convenience in the process of control and supervision which continues to prioritize the principles of fair competition, transparency, openness and fair treatment for all parties; therefore, the results can be accounted for in terms of physical, financial, and benefits (Amiruddin, 2012).

Many business people in Indonesia address existing business competition by doing various ways and sometimes even leading to deviant things (Meliala, 1993). One of them is to make a nominee agreement to win a project auction (Wicaksono, 2016). The purpose of nominee agreement here is to borrow the name of a company owned by someone else who is experienced in his/her field or commonly known by the term "borrowing flag". In this case, an individual/ business entity uses the name of another business entity to participate in the auction process for procurement of government goods/ services and acts for and on behalf of the business entity which name is borrowed (Pahlevi et al, 2017 and Fahruroji, 2015). This is also due to the large public interest in participating in the auction process for procurement of government goods/ services or commonly referred to as the auction; however, it is not balanced with the qualifications of capacity and capability of the company required in an election method to obtain goods/ construction work/ other service providers.

Borrowing the name of the business entity described above is actually an agreement only known between the owner and the borrower which the auction committee does not know about. To provide security to the owner of the company and to provide more space for the borrower to name the company, commonly, the agreement in the form of power of attorney is made by a notary, which of course has been approved by the board of directors. In this case, the owner of the company gives attorney to the borrower to carry out all activities related to one field of work, provided that the conditions they have agreed upon, as stated in the contents of the agreement they made together.

In corporate law, attorney grant is permitted for a company director. This is stated in Article 103 of Law No. 40 of 2007 concerning Limited Liability Companies (hereinafter referred to as Company Law) which stipulates that "director can provide written attorney to 1 (one) company employee or more or to others for and on behalf of the company to perform certain legal acts as described in the power of attorney". The power of attorney referred to in Article 103 of the Company Law is a special power of attorney.

In this study, the discussion that will be carried out is only limited to the process of procurement of government goods and services by using "provider of goods and services" especially in the field of "construction work". Based on the description of the background, the problem raised in this study is "legal relations between grantor and grantee of director's attorney in the implementation of procurement

\footnotetext{
${ }^{1}$ Aksara Lustitia Team, Compulsory Procurement Book, Presidential Regulation No. 16 of 2018 concerning Procurement of Government Goods/ Services completed with 13 regulations of the latest Government Goods/ Services Procurement Policy. Jakarta, Vmedia, 2018, page iii
} 
of government goods and/ or services" (study of the decision of the Mataram District Court number: 33/PID.SUS.TPK/2015/PN.MTR).

Then, the purpose of writing this thesis is to determine the legal relations between grantor and grantees of director's attorney in the procurement of goods/ services based on the decision of the Mataram District Court number: 33/PID.SUS.TPK /2015/PN.MTR.

The type of research used in writing this thesis is normative legal research. Methods in the research approach include case approach, statute approach, and conceptual approach.

\section{Discussion}

\section{Implementation of Procurement of Goods/ Services through Provider}

The procurement of goods/ services is an activity that starts from the identification of needs to the handover of work results (Isnandar et al, 2017). The provider must fulfill the qualifications in accordance with the provisions of the laws and regulations. In addition, the determination of competent providers requires a guideline for procurement agents as a work reference, so that the procurement of government goods/ services through provider runs appropriately, smoothly and in accordance with Presidential Regulation No. 16 of 2018 concerning Procurement of Government Goods and Services. Therefore, the government stipulates Government Regulation on Procurement of Goods/ Services Policy No. 9 of 2018 concerning Guidelines for Implementation of Procurement of Goods/ Services through Provider. Before implementing the procurement of goods and services, it is necessary to carry out analysis and evaluation of procurement requirements and planning. The implementation of procurement of government goods/ services through provider is a follow up activity on procurement planning that has been carried out by Budget User/ Attorney Budget User. Implementation of procurement of government goods/ services through provider includes preparation activities for procurement of government goods/ services through provider, preparation of provider selection, implementation of provider selection, implementation of contracts and handover of work results. ${ }^{2}$

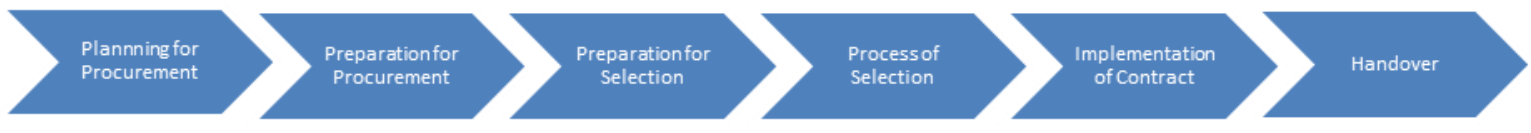

Figure 1. Stages of Procurement of Goods/ Services Through Providers

Procurement of goods and services is carried out by applying basic principles in accordance with Article 6 of Presidential Regulation No. 16 of 2018, including the following: efficient, effective, transparent, open, fair, competitive, and accountable. In addition to implementing the basic principles of procurement of government goods/ services above, the parties involved in procurement of government goods/ services must also comply with the procurement ethics of government goods/ services stipulated in Article 7 of Presidential Regulation No. 16 of 2018, as follows:

a. Carry out the task in an orderly manner accompanied by a sense of responsibility to achieve the goals, smoothness and accuracy of the objectives of the procurement of government goods/ services.

\footnotetext{
${ }^{2}$ Appendix of Procurement of Government Goods/ Services, Procurement Policy No. 9 of 2018 concerning Guidelines for the Implementation of Procurement of Goods/ Services through Provider, Aksara Lustitia Team, Compulsory Procurement Book, Presidential Regulation No. 16 of 2018 concerning Procurement of Government Goods/Services completed with 13 regulations of the latest Government Goods/Services Procurement Policy.
} 
b. Work professionally and independently and maintain the confidentiality of information that must be kept confidential in order to prevent irregularities in the procurement of government goods/ services.

c. Not affect each other directly or indirectly which results in unfair competition.

d. Accept and be responsible for all decisions determined in accordance with a written agreement with the parties concerned.

e. Avoid and prevent the occurrence of conflicts of interests from the involved parties, directly or indirectly, which result in unfair business competition in the procurement of government goods/ services.

f. Avoid and prevent waste and leakage of state finance.

g. Avoid and prevent abuse of authority and/or collusion.

h. Not accept, not offer, or not promise to give or receive gifts, rewards, commissions, rebates, and anything from or to anyone who is known or reasonably suspected to be related to the procurement of government goods/ services.

Legal Relations between Grantor and Grantee of Director's Attorney in the Procurement of Goods and Services (Study of the Decision of the Mataram District Court Number: 33/PID.SUS.TPK/2015/PN.MTR)

Engagement and agreement are one thing that is different. Engagement can emerge from an agreement and law. An agreement can lead to an engagement for the parties making the agreement. Engagement is a translation of the terms Dutch verbintenis and this term of engagement is commonly used in Indonesia. Engagement means things that bind people to one another. The binding thing is in fact in the form of action. Engagement is formulated as legal relations that occur between one person and another because of actions, events, or circumstances (Machun, 2004).

The engagement is regulated in book III of the Civil Code of Articles 1233-1456, where the nature of the engagement includes:

a. Open, meaning that the agreement can be carried out by anyone as long as it is not in compliance with the Law.

b. Regulating, meaning that the nature of civil law is not compelling but is agreed upon by both parties.

c. Completing, meaning that it may add or reduce the content of the agreement because it depends on the deal.

Meanwhile, the agreement is regulated in Book III (three) and Chapter II (two) of the Civil Code. Article 1313 of the Civil Code states that: "an agreement is an act which one person or more ties $\mathrm{him} / \mathrm{herself}$ to one person or more".

The applicable legal regulatory system is an open system. It means that everyone is free to enter into an agreement; whether it has been regulated in law (nominaat) or has not been regulated in law (innominaat) namely an agreement that emerges due to customs or development of era.

The business attorney agreement "borrowing flag" can also be referred to a borrowing-name agreement, which in the legal dictionary is known as nominee and is one form of innomenaat agreement because there are no rules governing it in the law. A nominee is someone who acts for the name of another party as a representative in a limited narrow sense and sometimes the term is used to signify an agent or guardian (Garner, 1999).

Meanwhile, the definition of nominee, in article 1 paragraph 4 (6) of the Directorate General of Tax Regulation Number PER-62/PJ.2009 concerning Prevention of Misuse of Double Taxation Approval, 
is a person or legal entity who has a property and/or income for interests or based on the mandate of the party who should be the owner of the property and/or based on the mandate of the party who actually enjoys the benefits or income on it.

In procurement of goods and services, the nominee agreement "borrowing flag with the provision of director's power of attorney" is often misused by business actors as the provider to win a project auction, as in the case below:

Based on the Decision of the Mataram District Court Number: 33/PID.SUS.TPK/2015.PN.MTR dated September 1, 2015 in the case of Construction Project for the Hajj Terminal and Indonesian Workers Building at the Transportation and Communication Information Agency of West Nusa Tenggara Province, the actions taken by the defendant were in the following way:

- On March 30, 2011, the procurement committee made an auction announcement for the Construction Project for the Hajj Terminal and Indonesian Workers Building. Prior to this information, Defendant II, Liustono Aspari, ST, MM contacted Defendant I H. Yudhi Abdilah to use the company owned by Defendant I H. Yudhi Abdilah, i.e. PT Serba Karya Abadi with the term "borrowing flag" to take part in the auction and carry out Construction Project for the Hajj Terminal and Indonesian Workers Building at the Transportation and Communication Information Agency of West Nusa Tenggara Province. Oral request for borrowing company or borrowing flag by Defendant II Liustono Aspari, ST, MM was approved by Defendant I H. Yudhi Abdilah. Furthermore, it was followed up by Defendant I H. Yudhi Abdilah and Defendant II Liustono Aspari, ST, MM made a power of attorney before a notary on April 1, 2011. The main content of the power of attorney stated that Defendant I H. Yudhi Abdilah as Director of PT Serba Karya Abadi gave attorney to Defendant II Liustono Aspari, ST, MM to take part in the procurement/ auction process until the physical implementation of work if PT Serba Karya Abadi was appointed as the winner of the auction in the Construction Project for the Hajj Terminal and Indonesian Workers Building at the Transportation and Communication Information Agency of West Nusa Tenggara Province. Furthermore, Defendant I H. Yudhi Abdilah provided data or documents from PT Serba Karya Abadi to Defendant II Liustono Aspari, ST, MM so that he would make and prepare offering documents for the PT Serba Karya Abadi. In the attachment to the offering letter (letter of support for personnel/ worker), it was stated that Defendant II Liustono Aspari, ST, MM was the staff (structural expert) from PT Serba Karya Abadi. However, in fact Defendant II Liustono Aspari, ST, MM was not a staff of PT Abadi Karya Abadi.

- Although the power of attorney was made for Defendant II Liustono Aspari, ST, MM to take part in the auction on behalf of PT Serba Karya Abadi, but in the implementation, Defendant I H. Yudhi Abdilah himself as Director of PT Serba Karya Abadi took part in the auction by registering his company to the procurement committee without delivering the power of attorney.

- On April 15, 2011 the auction winner for Construction Project of the the Hajj Terminal and Indonesian Workers Building at the Transportation and Communication Information Agency of West Nusa Tenggara Province was announced, in which the auction winner was PT Serba Karya Abadi. Furthermore, Defendant I H. Yudhi Abdilah along with Commitment Making Official for Transportation and Communication Information Agency of West Nusa Tenggara Province in the Field of Air Transportation, Ir. Nizarwansjah, MT signed a Construction Project Agreement for the Hajj Terminal and Indonesian Workers Building in Lombok International Airport on Transportation and Communication Information Agency of West Nusa Tenggara Province in 2011 Number: 027/09/DISHUBKOMINFO/IV dated 27 April 2011 and the Work Start Warrant Number: 027/13/DISHUBKOMINFO/IV dated May 4, 2011, with a contract value of IDR 7,398,899,000 (seven billion and three hundred ninety eight million and eight hundred ninety nine thousand rupiahs) with the period of execution of work for 180 (one hundred and eighty) calendar days starting April 27, 2011 up to October 23, 2011. 
- Based on the contract Number: 027/09/DISHUBKOMINFO/IV dated April 27, 2011 and the Work Start Warrant Number: 027/13/DISHUBKOMINFO/IV dated May 4, 2011, the one who had to carry out physical work and receive payment was Defendant I H. Yudhi Abdilah, but in the implementation, Defendant I H. Yudhi Abdilah handed over the work to Defendant II Liustono Aspari, ST, MM based on the power of attorney signed before Notary Abdullah, SH on April 1, 2011; however, the power of attorney was not submitted/ reported to the Commitment Making Official so that the administration of the work was still carried out and reported by Defendant I H. Yudhi Abdilah. This act contradicts article 87 paragraph (3) Presidential Regulation of the Republic of Indonesia Number 54 of 2010 concerning Guidelines for the Implementation of Government Goods/ Services Procurement stating that goods/ services providers are prohibited from transferring the implementation of main work based on contracts by subcontracting with other parties except for sharing a portion of the main work to the specialist provider of goods/ service.

The provision of director's attorney is important but this is not regulated in detail in the Company Law; for example, about how its application, its responsibilities, the limits of attorney giving, and the form of attorney. Thus, in implementing the director's attorney agreement, we cannot view it based on the Company Law alone but also other laws and regulations, one of which is the Civil Code which regulates the terms of the legal agreement.

The conditions for the validity of an agreement, mentioned in Article 1320 of the Civil Code include: the deal which binds the parties, the competent ability to make an agreement, a certain matter, and a lawful cause.

The first condition is a deal which is the beginning of the agreement, as stated in article 1321 of the Civil Code "there is no legal right if it is agreed to be due to an error or obtained by coercion or fraud." The two parties that entered into the agreement must agree on the main matters of the agreement held. Deal means conformity, suitability, meeting the will of the contracting party or an agreed statement of intention between the parties. The deal element is divided into two, as follows: (Badrulzaman et al, 2006).

1. Offer is a statement of the offering party.

2. Acceptance is a statement of the party receiving the offer.

The second condition, the person making the agreement must be competent according to the law. Principally, everyone who is mature and healthy in mind, is competent according to the law.

The third condition states that an agreement must be about a certain matter. This requirement explains that there must be a clear object of agreement. So, an agreement cannot be carried out without certain object. As mentioned in Article 1333 which reads: an agreement must have the principal of an item which has the least specified type.

The fourth condition is regarding a lawful cause. Article 1335 which states that "an agreement without cause, or that has been made for something that is false or forbidden, has no power." The purpose of this article is if an agreement is contrary to law, decency or public order, then the agreement has no strength or commonly called null and void by law.

Furthermore, Article 1337 of the Civil Code states that "a cause is prohibited if it is prohibited by law or if it is contrary to good morality or public order." The purpose of the article is a reason stated to be prohibited or commonly referred to as non-halal if it is against the law, decency and public order. 
The first two conditions are called subjective conditions, because they are about the subject of the agreement. If these conditions are not fulfilled, then the agreement can be canceled. In addition, the last two conditions are called objective conditions, because of the agreement itself or the object of the legal act, and if these conditions are not met, then the agreement is null and void.

In addition to having to fulfill the legal requirements of the agreement, the parties must also pay attention to the legal principles of the agreement that have been valid and use it as guideline in making agreements, including: Principle of Consensus, Principle of Binding Strength (Pacta Sunt Servanda), Principle of Contracting Freedom, Principle of Good Faith, and Principle of Personality.

\section{Principle of Consensus}

This principle means that an agreement is born since a deal is reached between the two parties. The principle of consensus can be concluded in Article 1320 paragraph (1) of the Civil Code, which states that: "one of the legal requirements of the agreement is the agreement of both parties". This means that the agreement is generally not formally held, but enough with a deal between the two parties. Deal is the correspondence between the will and the statement made by both parties. ${ }^{3}$

\section{Principle of Binding Strength (Pacta Sunt Servanda)}

Principle of Pacta Sunt Servanda relates to the consequences of the agreement. This is concluded from Article 1338 paragraph (1) of the Civil Code which states that: "all agreements, made legally, apply as laws for those who make them". It means that the parties must obey and carry out the obligations in the agreement, as they obey the law.

\section{Principle of Contracting Freedom}

The principle of contracting freedom can be analyzed from the provisions of Article 1338 paragraph (1) of the Civil Code, which states that: "all agreements, made legally, apply as laws for those who make them". The principle of contracting freedom is a principle that gives freedom to parties, to: ${ }^{4} 1$ ) Make or not make an agreement; 2) Enter into agreements with anyone; 3) Determine the contents of the agreement, implementation and requirements; 4) Determine the form of the agreement; i.e. written or oral forms.

\section{Principle of Good Faith (Goede Trouw)}

Article 1338 paragraph (3) of the Civil Code explains that "the agreement must be carried out in good faith" which, in the case of carrying out the agreement, the parties must implement what has been the subject of the agreement they made on the basis of good faith or willingness.

The principle of good faith is divided into two types, relative and absolute good faith. In relative good faith, people pay attention to the real behavior and attitudes of the subjects or the parties to the agreement. Meanwhile, in absolute good faith, the judgment lies in common sense and justice. Then, objective measures are made to assess the situation (impartial judgment) according to objective norms. ${ }^{5}$

\section{Principle of Personality}

The principle of personality is the principle determining that someone who will do and or make an agreement only aims to take care of the interests of the parties. It can be seen in Article 1315 of the Civil Code which is formulated as follows: "Generally, no one can bind him/herself in his own name or ask for an appointment, except for him/herself".

Article 1315 of the Civil Code is reinforced by the formulation of Article 1340 of the Civil Code which states that: "Agreements only apply between parties who make them".

\footnotetext{
${ }^{3}$ Salim H. S. Loc. Cit., page 10

${ }^{4}$ Salim H. S. Loc. Cit., page 9

${ }^{5}$ Salim H. S. Loc. Cit., page 11
} 
If associated with article 1338 and 1320 Civil Code where the director's attorney agreement is carried out by the two defendants, legal relations between them were created when they had a deal to enter into an agreement and this agreement arouse because one of the principles of the agreement; i.e. the principle of contracting freedom. It means that everyone can enter into any agreement, whether or not it is regulated by law. However, agreements made are not necessarily valid, because the Business Attorney Agreement made by the two defendants is included in the nominee agreement, which is in the procurement of government goods/ services, it is a matter that should not be carried out by business actors as the provider because it is contrary to the provisions of the contents of Article 78 Paragraph 1 letter a Presidential Regulation No. 16 of 2018 concerning procurement of goods and services which reads "it is prohibited to submit false/ incorrect documents or information to meet the requirements specified in the document". Thus, what was committed by the two defendants could be considered an attempt to smuggle the law. The director's attorney made by the two defendants is deemed not to fulfill one of the legal requirements of the agreement, i.e. the existence of lawful cause or causa and also contradicts the principle of good faith in the agreement.

By understanding the concept of lawful cause/ causa, the agreement that they made should not conflict with article 1337 of the Civil Code regarding "agreement that does not conflict with the law on public order and morality". In this case, the agreement they did has deviated and did not implement the legislation.

Observing the actions described in the indictment above, it is concluded that the two defendants indeed had bad intentions when making the agreement in borrowing flag of other company; i.e. with the intention and purpose of manipulating corporate data so that they can follow the auction process at the Construction Project for the Hajj Terminal and Indonesian Workers Building at the Transportation and Communication Information Agency of West Nusa Tenggara Province in 2011.

In addition, the director's attorney agreement of Defendant I and Defendant II did not deem to fulfill one of the objective conditions of the agreement; so that the agreement is null and void by law. It means that the legal relations of the two defendants were initially considered to have never had one engagement; thus, there is no basis for both parties to file a claim before the judge.

\section{Conclusion}

Based on the previous description, it can be concluded as follows:

Legal relations between them were created when they had a deal to enter into an agreement and this agreement arouse because one of the principles of the agreement; i.e. the principle of contracting freedom.

The director's attorney agreement made by the two defendants is included in the nominee agreement, which is in the procurement of government goods/ services, it is a matter that should not be carried out by business actors as the provider and it could be considered an attempt to smuggle the law. It is deemed not to fulfill one of the legal requirements of the agreement, i.e. the existence of lawful cause or causa and also contradicts the principle of good faith in the agreement. Moreover, it was not deemed to fulfill one of the objective conditions of the agreement; so that the agreement is null and void by law. It means that the legal relations of the two defendants were initially considered to have never had one engagement; thus, there is no basis for both parties to file a claim before the judge. 


\section{References}

\section{Books}

Amiruddin, A. (2012). Pemberantasan Korupsi dalam Pengadaan Barang dan Jasa melalui Instrumen Hukum Pidana dan Administrasi. Media Hukum, 19(1).

Badrulzaman, M. D., Perikatan, K. H., \& Bakti, P. C. A. (2006). KUHPerdata Buku III. Bandung. Alumni.

Fahruroji, M. (2015). Tinjauan hukum perjanjian nominee terhadap pemberian kuasa penanam modal asing dalam kepemilikan saham perseroan terbatas.

Garner, B. A. (1999). Black’s Law Dictionary With Guide to Pronunciation, Cet. 7.

Isnandar, Y., Purwadi, H., \& Handayani, I. G. A. K. R. (2017). Implementasi Peraturan Presiden Nomor 54 Tahun 2010 Tentang Pengadaan Barang dan Jasa Pemerintah di Kabupaten Sukoharjo. Jurnal Hukum dan Pembangunan Ekonomi, 5(2).

Machun, S. S. S. (2004). Hukum Perjanjian Perhutangan, Terjemahan Seksi hukum Perdata Fakultas Hukum. Yogyakarta: Universitas Gadjah Mada.

Meliala, A. (1993). Praktik bisnis curang. Pustaka Sinar Harapan.

Pahlevi, K., Prananingtyas, P., \& Lestari, S. N. (2017). Analisis Yuridis Terhadap Penggunaan Saham Pinjam Nama (Nominee Arrangement) Ditinjau Dari Peraturan Perundang-Undangan Di Indonesia. Diponegoro Law Journal, 6(1), 1-19.

Pengorganisasian dan pengembangan masyarakat: model \& strategi pembangunan berbasis kerakyatan. Humaniora.

Salim, H. S., \& Nurbani, E. S. (2014). Penerapan Teori Hukum Pada Penelitian Disertasi dan Tesis. PT Raja Grafindo Persada, Jakarta.

Salim. H.S. (2015). Hukum Kontrak Teori dan Teknik Penyusunan Kontrak, cetakan ke sepuluh, Jakarta, Sinar Grafika,

Wicaksono, L. S. (2016). Kepastian Hukum Nominee Agreement Kepemilikan Saham Perseroan Terbatas. Ius Quia Iustum Law Journal, 23(1), 42-57.

Legislation

Civil Code.

Criminal Code.

Indonesia, Law No. 3 of 1982 concerning Obligatory Registration from Company, State Gazette of the Republic of Indonesia of 1982 No. 7.

Indonesia, Law No. 8 of 1997 concerning Company Documents, State Gazette of the Republic of Indonesia No. 18 of 1997. 
Law No. 5 of 1999 concerning Prohibition of Monopolistic Practices and Unfair Business Competition, State Gazette of the Republic of Indonesia No. 33 of 1999.

Law No. 18 of 1997 concerning Construction Service, State Gazette of the Republic of Indonesia of 1999 No. 54.

Law No. 40 of 2007 concerning Limited Liability Company, State Gazette of the Republic of Indonesia of 2007 No. 206.

Presidential Regulation of the Republic of Indonesia No. 53 of 2010, which has been amended several times, the latest by the Government Regulation of the Republic of Indonesia No. 45 of 2013 concerning Procedures for Implementing the State Budget. State Gazette of the Republic of Indonesia of 2013 No. 103.

Government Regulation of the Republic of Indonesia No. 12 of 2019 concerning Regional Financial Management; In lieu of Government Regulation No. 58 of 2005 concerning Regional Financial Management. State Gazette of the Republic of Indonesia 2019 No. 42.

Presidential Regulation No. 54 of 2010 concerning Procurement of Government Goods/ Services which has been amended several times, the latest by Presidential Regulation No 16 of 2018 concerning Procurement of Government Goods/ Services, State Gazette of the Republic of Indonesia of 2018 No. 33.

Policy Institution Regulations of the Procurement of Government Goods/ Services No. 7 of 2018 concerning Planning Guidelines of the Procurement of Government Goods/ Services, State Gazette of the Republic of Indonesia of 2018 No. 760.

Policy Institution Regulations of the Procurement of Government Goods/ Services No. 8 of 2018 concerning Self-Management Guidelines, State Gazette of the Republic of Indonesia of 2018 No. 761.

Policy Institution Regulations of the Procurement of Government Goods/ Services No. 9 of 2018 concerning Planning Guidelines of the Procurement of Government Goods/ Services through Provider, State Gazette of the Republic of Indonesia of 2018 No. 762.

Policy Institution Regulations of the Procurement of Government Goods/ Services No. 11 of 2018 concerning Electronic Catalog, State Gazette of the Republic of Indonesia of 2018 No. 764.

Policy Institution Regulations of the Procurement of Government Goods/ Services No. 12 of 2018 concerning Guidelines for Procurement of Goods/ Services Excluded on Procurement of Government Goods/ Services, State Gazette of the Republic of Indonesia of 2018 No. 765.

Policy Institution Regulations of the Procurement of Government Goods/ Services No. 15 of 2018 concerning Actors of Procurement of Goods/ Services, State Gazette of the Republic of Indonesia of 2018 No. 768.

Policy Institution Regulations of the Procurement of Government Goods/ Services No. 16 of 2018 concerning Procurement Agent, State Gazette of the Republic of Indonesia of 2018 No. 770. 
Policy Institution Regulations of the Procurement of Government Goods/ Services No. 17 of 2018 concerning Blacklist Sanction in Procurement of Goods/ Services, State Gazette of the Republic of Indonesia of 2018 No. 771.

Policy Institution Regulations of the Procurement of Government Goods/ Services No. 19 of 2018 concerning System and Policy Development on Procurement of Goods/ Services, State Gazette of the Republic of Indonesia of 2018 No. 772.

Website

https://www.bambanghariyanto.com/2013/10/organ-organ-dalam-pt.html. diakses tgl 10 Desember 2018. https://www.djkn.kemenkeu.go.id/2013/artikel/sejarah-lelang

https://www.suara.com/news/2017/09/15/040000/kpk-80-persen-korupsi-terkait-pengadaan-barang-danjasa. diakses tgl 5 November 2018.

https://muhammadaiz.wordpress.com. Ilmu-Hukum. Diakses tanggal 20 januari 2019.

\section{Copyrights}

Copyright for this article is retained by the author(s), with first publication rights granted to the journal. This is an open-access article distributed under the terms and conditions of the Creative Commons Attribution license (http://creativecommons.org/licenses/by/4.0/). 